\title{
The effect of power (US intensity $x$ US duration) on shuttlebox avoidance acquisition in goldfish
}

\author{
DOMINIC J. ZERBOLIO, JR. and LINDA L. WICKSTRA \\ University of Missouri-St. Louis, St. Louis, Missouri 63121
}

\begin{abstract}
A factorial arrangement of four shock intensity levels $(7.5,10,15$, or $20 \mathrm{~V}$ ac) by three shock durations $(100,200$, or $400 \mathrm{msec}$ ), and NO US control was used to examine the effect of power (shock intensity $x$ shock duration) on CAR shuttlebox acquisition in goldfish (Carassius auratus). On CAR performance, increasing power level at first increased then decreased avoidance acquisition indicating an inverted "U" function. On total activity, shuttle rates by NO US controls were high. Low levels of power produced a substantial decrease in total activity. Increasing power yielded first an increase then decrease in shuttle rates. Thus, an inverted " $U$ " function between total activity and power, excluding the control level, is also evident. The initial effect of low power levels is to depress total activity.
\end{abstract}

Several studies have used shock in investigating the acquisition of a conditioned avoidance response (CAR) in goldfish (Carassius auratus) e.g., Behrend and Bitterman, 1962; Frunkin and Brookshire, 1969; Scobie and Fallon, 1974; Woodard and Bitterman, 1971, 1973; Zerbolio, 1973. But little work has been done in examining the effect of shock on fish behavior. Bintz (1971) found an inverted "U" function between CAR performance and increasing shock intensity. Scobie and Herman (1972) investigated both shock level and duration on detection, reaction, escape, and debilitation thresholds in goldfish and concluded that "the receptor system (of fish) is relatively insensitive to stimulus (shock) duration." Scobie and Herman admit being puzzled by this since at the same shock intensity level, a subject run at $400 \mathrm{msec}$ is subjected to eight times the power (intensity $x$ duration) of a subject run at $50 \mathrm{msec}$. But since Scobie and Herman did not examine the effect of power on the acquisition of a CAR, the present study attempts to do so.

\section{METHOD}

\section{Subjects}

One hundred ninety-five goldfish, $5-6 \mathrm{~cm}$ long, obtained in two shipments (March and June) from Ozark Fisheries, Stoutland, Missouri, were used. All animals were housed in a 50 -gal aquarium until $48 \mathrm{~h}$ prior to use, when they were transferred to 10 gal aquaria in the experimental chamber.

\footnotetext{
Apparatus

Subjects were run in two identical $29.2 \times 11.4 \times 11.4 \mathrm{~cm}$ shuttle tanks (Zerbolio, 1973) separated into two compartments by a center hurdle $6.35 \mathrm{~cm}$ high. Water clearance over the hurdle top was maintained at $2.5 \mathrm{~cm}$. Photocells located at the ends of hurdle monitored activity. Blue $7-\mathrm{W} 110 \mathrm{~V}$ ac lamps at each end of the tank served as the CS. The US shock was generated by variable transformers, individually metered to allow constant monitoring, and delivered into the tanks via $28 \times 10.2 \mathrm{~cm} 22 \mathrm{~g}$ stainless steel plates mounted along both sides of the tank. Temperature $\left(21.1^{\circ} \mathrm{C}\right)$ and $\mathrm{pH}(7.00 \pm .1)$ were held constant, all tanks were well filtered and aerated, and fish were fed daily
}

throughout the experiment. All events were programmed and recorded with appropriate circuitry.

\section{Procedure}

Twelve groups of 15 subjects each comprised a three shock duration $(100,200$, or $400 \mathrm{msec})$ by four shock intensity $(7.5$, 10,15 , or $20 \mathrm{~V} \mathrm{ac}$ ) factorial design. Scobie and Herman (1972) suggest that shock intensity can be stated in volts $/ \mathrm{cm}$ for cross comparison purposes, which would make our shock levels .676, $.901,1.351$, and $1.802 \mathrm{~V} / \mathrm{cm}$, respectively. An additional 15 subjects NO US control group was run. All animals received 100 trials in a single session. Each trial consisted of a 7.5-sec CS-US interval and a 2.5 -sec US period with shock occurring at its onset and offset. The ITI was $60 \mathrm{sec}$. The CS onset occurred only on the side occupied by the fish. Initial responses occurring in the CS-US interval were recorded as avoidances and terminated the trial. Initial responses during the US period were recorded as escapes and terminated further stimulation.

\section{RESULTS}

No learning differences between the March and June shipments were observed, suggesting that Agranoff and Davis's (1968) finding of seasonal variation may be due to the way fish are maintained between receipt and running as suggested by Fjerdingstad (1974).

The mean number of avoidances for all CAR groups by blocks of 20 trials are shown in Figure 1. A three-way ANOVA (Winer, 1962) shows significant main effects for shock duration $\left(\mathrm{F}=4.571, \mathrm{df}=2 / 168, \mathrm{p}<.05, \mathrm{\omega}^{2}\right.$ $=.025)$, shock intensity $(\mathrm{F}=6.199, \mathrm{df}=3 / 168, \mathrm{p}<.01$, $\left.\omega^{2}=.054\right)$, and blocks of training $(\mathrm{F}=123.949$, $\mathrm{df}=$ $\left.4 / 672, p<.01, \omega^{2}=.239\right)$. Significant interaction effects for Duration by Intensity $(F=10.841$, df $=$ $\left.6 / 168, \mathrm{p}<.01, \omega^{2}=.206\right)$, Blocks by Intensity $(\mathrm{F}=$ $\left.4.105, \mathrm{df}=12 / 672, \mathrm{p}<.01, \omega^{2}=.018\right)$, and Blocks by Duration by Intensity $(F=2.828, d f=24 / 672, p<.01$, $\omega^{2}=.021$ ) were also observed. Note that the blocks of training and Duration by Intensity interaction accounted for substantial proportions of the total variance (i.e., .239 and .206 , respectively).

A two-way ANOVA on total shuttles shows 


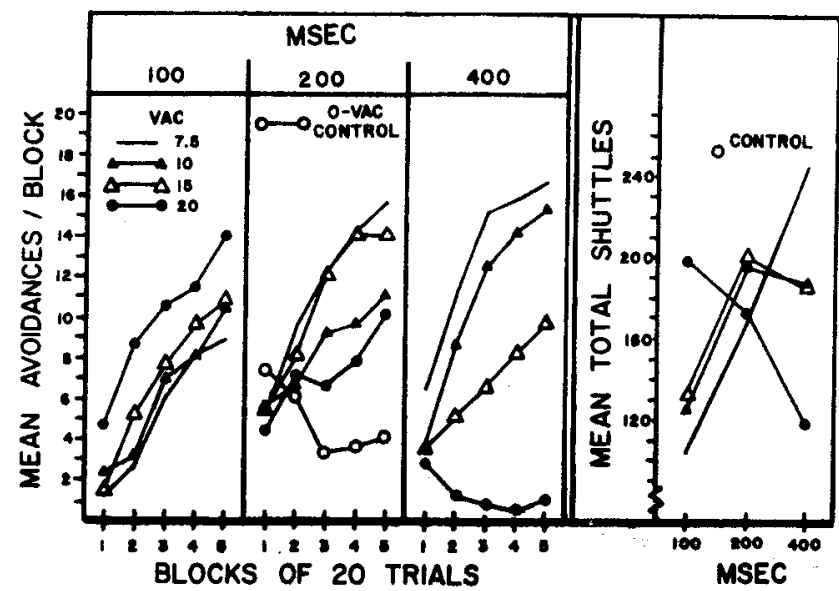

Figure 1. The mean avoidance per block for four shock intensities $(7.5,10,15,20 \mathrm{~V}$ ac) at each of three shock durations $(100,200$, and $300 \mathrm{msec})$ and, in the center panel, the NO US (0-V ac) shock control. Also shown are the mean total shuttles for each group, including the NO US control.

significant effects for duration $(\mathrm{F}=5.686, \mathrm{df}=2 / 168$, $\mathrm{p}<.01, \omega^{2}=.044$ ) and a Duration by Intensity interaction $\left(\mathrm{F}=5.289, \mathrm{df}=6 / 168, \mathrm{p}<.01, \omega^{2}=.121\right)$. Again, the Duration by Intensity interaction accounts for a substantial portion of the total variance (.121).

The power levels (shock intensity $\mathrm{x}$ shock duration) were calculated for all groups, including the NO US control group, and appears in Table 1 . A common overall avoidance median was calculated. The proportion of each group above the overall avoidance median also appears in Table 1. For groups having common power levels (i.e., 1.50, 2.00, 3.00, and 4.00), $\chi^{2}$ tests indicated they did not differ in proportion above the common median $\left(\chi^{2}=2.17,1.57,1.00\right.$, and 1.35 , respectively with $\mathrm{df}=1$ ) and were combined for further analysis. An overall $\chi^{2}$ shows that the proportion of subjects above the common avoidance median differs markedly across power levels $\left(\chi^{2}=53.385, \mathrm{df}=8, \mathrm{p}<.01\right)$.

A comparable analysis was performed on the total shuttle rate data. The groups with common power levels $(1.50,2.00,3.00$, and 4.00$)$ did not differ in proportion above the common shuttle rate median $\left(\chi^{2}=.13,1.00\right.$, 1.21 , and .63 , respectively, with $\mathrm{df}=1)$. An overall $\chi^{2}$ shows that the proportion of subjects above the common shuttle rate median differs markedly across power levels $\left(\chi^{2}=40.063, \mathrm{df}=8, \mathrm{p}<.01\right)$.

\section{DISCUSSION}

These data clearly show that power (time $x$ intensity of the US) affects both the CAR acquisition and total shuttle rate of goldfish. The proportion of goldfish exhibiting better than median CAR performance (Table 1) first increases and then decreases with increasing power, an inverted " $U$ " function. This effect is also evident from an inspection of Figure 1. But the effect of power on total activity or shuttle rate is different. Compared to the control levels, the initial effect of shock at low power levels is to depress activity rate. Increasing power from these low levels first produces an increase and then a decrease in total activity. One could speculate that increassing power levels from low to high first motivate the animals performance to an optimum level and then further power increases produce increasing debilitation, although all of our animals survived our procedures. But what is clear from these data is that shock, especially at low levels, does not increase, but decreases total activity rate as compared to NO US control activity levels. Further studies examining the effect of increasing power by blocks of training are indicated.

In sum then, it is clear from the present data that, although shock duration may not affect detection, reaction, escape, or debilitation thresholds per se (Scobie \& Herman, 1972), when varied with shock intensity in a CAR shuttlebox situation. it has a marked effect on both CAR acquistion and total activity rate.

\section{REFERENCES}

Agranoff, B. W., \& Davis, R. E. The use of fishes in studies on

Table 1

The Number in Each Group and by Power Level that are Above the Common Median Both for Avoidances and Total Shuttles

\begin{tabular}{|c|c|c|c|c|c|c|c|c|c|}
\hline $\begin{array}{l}\text { Power } \\
\text { (SEC } \times \text { VAC) }\end{array}$ & 0 & .75 & 1.00 & 1.50 & 2.00 & 3.00 & 4.00 & 6.00 & 8.00 \\
\hline $\begin{array}{l}\text { Groups } \\
(\mathrm{N}=15 \text { each) }\end{array}$ & $\begin{array}{l}\text { Con- } \\
\text { trol }\end{array}$ & $.100 \times 7.5$ & $.100 \times 10$ & $\begin{array}{l}.100 \times 15 \\
.200 \times 7.5\end{array}$ & $\begin{array}{l}.100 \times 20 \\
.200 \times 10\end{array}$ & $\begin{array}{l}.200 \times 15 \\
.400 \mathrm{~s} 7.5\end{array}$ & $\begin{array}{l}.200 \times 20 \\
.400 \times 10\end{array}$ & $.400 \times 15$ & $\begin{array}{l}.400 \\
\times 20\end{array}$ \\
\hline $\mathrm{N}$ by Power & 15 & 15 & 15 & 30 & 30 & 30 & 30 & 15 & 15 \\
\hline \multicolumn{10}{|c|}{$\begin{array}{l}\text { Avoidances } \\
\text { Number Above Common Median }\end{array}$} \\
\hline By Group & 1 & 5 & 5 & $\begin{array}{r}6 \\
11\end{array}$ & $\begin{array}{r}11 \\
8\end{array}$ & $\begin{array}{l}13 \\
13\end{array}$ & $\begin{array}{r}12 \\
8\end{array}$ & 5 & 0 \\
\hline By Power & 1 & 5 & 5 & 17 & 19 & 26 & 20 & 5 & 0 \\
\hline $\begin{array}{c}\text { Proportion Ab } \\
\text { By Power }\end{array}$ & $\begin{array}{l}\text { ve Com } \\
.07\end{array}$ & $\begin{array}{l}\text { iedian } \\
.33\end{array}$ & .33 & .57 & .63 & .87 & .67 & .33 & .00 \\
\hline $\begin{array}{l}\text { Total Shuttles } \\
\text { Number Above }\end{array}$ & Commc & & & & & & & & \\
\hline By Group & 9 & 1 & 4 & $\begin{array}{r}6 \\
8\end{array}$ & $\begin{array}{r}9 \\
8 \\
17\end{array}$ & $\begin{array}{l}11 \\
13\end{array}$ & $\begin{array}{r}12 \\
9\end{array}$ & 6 & 2 \\
\hline By Power & 9 & 1 & 4 & 14 & 17 & 24 & 21 & 6 & 2 \\
\hline $\begin{array}{l}\text { Proportion Ab } \\
\text { By Power }\end{array}$ & $\begin{array}{l}\text { ve Com } \\
.60\end{array}$ & $\begin{array}{l}\text { ledian } \\
.07\end{array}$ & .27 & .46 & .57 & .80 & .70 & .40 & .13 \\
\hline
\end{tabular}

Note-The groups in the 1.50, 2.00, 3.00, and 4.00 power levels do not differ either on avoidances or total shuttles. 
memory formation. In D. Ingle (Ed.), The central nervous system and fish behavior. Chicago: University of Chicago Press, 1968.

Behrend, E. R., \& Bitterman, M. E. Avoidance conditioning in the goldfish: exploratory studies of the CS-US interval. American Journal of Psychology, 1962, 75, 18-34.

Bintz, J. Between and within subject effect of shock intensity on avoidance in goldfish. Journal of Comparative and Physiological Psychology, 1971, 75, 92-97.

Fjerdingstad, E. J. Seasonal changes in goldfish learning? Science, $1974,183,1321$.

Frunkin, K., \& Brookshire, K. Conditioned fear training and later avoidance learning in the goldfish. Psychonomic Science, $1969,16,159-160$.

Scobie, S., \& Fallon, D. Operant and pavlovian control of a defensive shuttle response in goldfish (Carassius auratus). Journal of Comparative and Physiological Psychology, 1974, 86, 858-866.
Scobie, S., \& Herman, B. Detection, reaction, escape, and debilitation thresholds for electric shock in goldfish. Learning and Motivation, 1972, 3, 442-456.

Winer, B. J. Statistical principles in experimental design. New York: McGraw-Hill, 1962.

Woodard, W. T., \& Bitterman, M. E. Classical conditioning of goldfish in the shuttlebox. Behavior Research Methods and Instrumentation, 1971, 3, 193-194.

Woodard, W. T., \& Bitterman, M. E. Pavlovian analysis of avoidance conditioning in the goldfish (Carassius auratus). Journal of Comparative and Physiological Psychology, 1973, 82, 123-129.

Zerbolio, D. J. Temperature-dependent learning in goldfish: a multi-trial active avoidance situation. Behavioral Biology, $1973,8,775-761$.

(Received for publication January 13, 1975.)

Bulletin of the Psychonomic Society

1975, Vol. 5 (4), 347-349

\title{
Individual differences in the ease of imagining the faces of others
}

\author{
J. DON READ and RICHARD H. PETERSON \\ University of Lethbridge, Lethbridge, Alberta Canada T1K $3 M 4$
}

\begin{abstract}
The time required for subjects to imagine the faces of other persons was measured and then correlated with ratings assigned by these same subjects to features (i.e., recency, frequency, emotional involvement) of their interactions with these others. The results demonstrated that the ratings and the imaginal latencies were significantly correlated; however, the relative importance of certain features of the interaction as well as the direction of the relationship varied dramatically from one subject to another.
\end{abstract}

As early as 1883 , Galton (1908) observed individual differences with respect to the ease with which people could recall or visualize the features of friends. Galton regarded these differences as being reflections of the differences in the degree of voluntary control over memory imagery possessed by these individuals. Whereas there is considerable evidence at present to indicate that people do differ reliably along dimensions such as the controllability and vividness of imagery (e.g., Marks, 1972; Richardson, 1972), it is reasonable to assume that intraindividual variability on these dimensions for a variety of stimuli is related to the particular characteristics of that which is being imaged. We decided to follow this line of reasoning a few steps further by developing several dimensions along which personal interactions could be categorized and then trying to

This research was supported by Grant $A 8350$ from the National Research Council of Canada and by University of Lethbridge Grant 71-1069. The authors wish to thank Mark L. Sandilands for his assistance in data analy sis. An earlier draft of this paper was greatly improved by the helpful comments and suggestions of Roger Barnsley, Sam C. Brown, and John T. Hamilton. A portion of this research was presented at the Canadian Psychological Association Meetings, Windsor, Ontario, June, 1974.

Requests for reprints should be sent to J. Don Read, Department of Psychology, The University of Lethbridge, Lethbridge, Alberta, Canada, T1 K 3M4. relate these measurements to the ease of recalling what someone looks like. The three selected for investigation were: emotional involvement, recency, and frequency. Whereas it would be possible to produce differences along these dimensions experimentally, a correlational study was designed in which ease of recall was correlated with each of the dimensions for people already known to the subject. In short, since we have all interacted with others in a great variety of ways and, presumably, the characteristics of these interactions may be recalled, the experiment was designed to take advantage of this wide variety of interaction.

\section{METHOD}

\section{Subjects}

Sixteen second semester psychology students completed the 1-h experiment either for extra class credit or $\$ 3.00$ at their choice.

\section{Materials}

A list of 63 names was constructed such that a wide variety of publicly known figures as well as personal acquaintances for each subject were included. Specifically, the list included relatives, close friends, local celebrities, well known television and movie entertainers, sports figures, and, finally, well known figures in national and international politics. For a number of relatives and 